\title{
EFFECT OF BOROSILICATE GLASS WASTES AND SYNTHETIC SILICA ON CEMENT PRODUCTS PROPERTIES
}

\author{
Galyna Kotsay1, ${ }^{1}$, Aleksandra Brzóska ${ }^{1}$
}

https://doi.org/10.23939/chcht15.02.312

\begin{abstract}
This paper presents the findings of research study on the effect of borosilicate glass wastes on properties of cement paste and mortar. The borosilicate glass contains three times less alkali than soda-lime glass and about $12 \%$ of boron oxide, so pozzolanic activity of borosilicate glass is three times higher compared to sodalime glass. In order to increase the pozzolanic activity of glass precipitated synthetic silica was used. Mathematical models were used in order to test the effect of synthetic silica on pozzolanic activity of borosilicate glass. Test results indicate that replacement of $1 \%$ of borosilicate glass by synthetic silica increased the pozzolanic activity up to $9.4 \mathrm{mg} \mathrm{CaO} / \mathrm{g}$ of additive. By adding $5 \%$ of borosilicate glass instead of cement, the standard compressive strength is reduced by about $20 \%$. However, complex additive of borosilicate glass $(2-5 \%)$ and synthetic silica $(0.5 \%)$ increased initial compressive strength of cement mortars to $10 \%$.
\end{abstract}

Keywords: borosilicate glass, synthetic silica, pozzolanic activity, strength.

\section{Introduction}

Nowadays, it is still a challenge to use glass wastes in construction sector. Therefore, in many papers, researchers have considered the possibility of recycling cullet derived from glass packaging, cathode-ray tubes, windows, or windscreens [1-7]. It has been proposed to use for cement production as small aggregate, pozzolanic additive or chemical admixture [8-13]. However, tests results were inconclusive, because various types of glass exhibited different reactivity. It happened due to the presence of modifiers in glass that occurred besides the amorphous silicon dioxide, and reduced the degree of bonding of silicon tetrahedra, which changed the glass reactivity.

\footnotetext{
${ }^{1}$ Warsaw University of Technology,

Faculty of Civil Engineering, Mechanics and Petrochemistry,

17, Lukasiewicza St., 09-400 Plock, Poland

.galyna.kotsay@pw.edu.pl

(c) Kotsay G., Brzóska A., 2021
}

Nevertheless, glass waste is considered as a valuable product for cement and concrete production. Usage of fine-ground glass as a mineral additive allows to replace cement, so, it decreases the energy consumption and $\mathrm{CO}_{2}$ emission. On the other hand, fine-ground glass modifies the structure of the cement paste as a result of reaction of amorphous silicon dioxide with calcium hydroxide to form a hydrated calcium silicate.

Still, fine-ground glass used in concrete can be not only an alternative mineral additive but also a micro-filler. However, usually, soda-lime glass contains up to $14 \%$ of alkali, and it may lead to alkali corrosion. It occurs inside concrete and it consists in reacting of alkali with reactive silica from the aggregate. Product of such reaction is a gel that absorbs water and increases its own volume causing osmotic pressure, then expansion and, finally, cracking of the concrete. Another risk is related to the content of calcium ions in the cement paste, as they replace alkali ions in the gel. It causes the secondary transport of sodium and potassium ions into the solution of cement paste in concrete and continues alkaline reaction. In comparison with the control mixture, an increase in the content of glass aggregates decreased compressive strength [4], because between glass aggregates and cement matrix there was a weak bond. However, incorporation of expanded glass aggregates caused increase in strength as a result of pozzolanic reaction of finer glass particles.

It ought to be noticed that part of the glass waste is borosilicate glass. When comparing it with soda-lime glass, it contains three times less alkali and circa about $12 \%$ of boron oxide. Because of its unique physicmechanical and chemical properties, the borosilicate glass becomes more and more popular. It is used for the production of laboratory glassware, medical glassware, kitchen utensils and in the lighting industry, where $\mathrm{SiO}_{2}$ and $\mathrm{B}_{2} \mathrm{O}_{3}$ are glass-forming oxides [14]. Depending on the number of modifiers and silicon dioxide, boron ions may be either three- or four-coordinate. In the glass where with the ratio $\mathrm{R}_{2} \mathrm{O} / \mathrm{B}_{2} \mathrm{O}_{3}<1 / 3\left(\mathrm{R}\right.$ is $\mathrm{Na}^{+}$or $\left.\mathrm{K}^{+}\right)$, boron was three-coordinate and chemically unstable, so, it was easily leached from the structure of glass, whereas with coefficient $\mathrm{R}_{2} \mathrm{O} / \mathrm{B}_{2} \mathrm{O}_{3}>1.6$ and the $\mathrm{SiO}_{2}$ content from 71 to $80 \%$ and with $\mathrm{R}_{2} \mathrm{O} / \mathrm{B}_{2} \mathrm{O}_{3}>4$ and $\mathrm{SiO}_{2}$ from 44 to 
$64 \%$, boron ions were four-coordinate and together with silicon oxide formed a glass structure [15].

Lee et al. [5] presents combined use of borosilicate glass powder as a mineral additive and fine aggregate in order to produce neutron shielding mortar. The borosilicate glass powder used increased the compressive strength of the mortar mixture and shielded $86 \%$ of additional thermal neutron. Moreover, $20 \%$ of borosilicate glass powder that replaced cement, enabled to control the expansion of alkali silicate reaction.

It is already known that in cement paste, borates are among admixtures that tend to delay binding and hardening of cement paste [16]. Boric acid delays reaction of tricalcium aluminate with gypsum, while, formation of borate interfaces inhibits the change of ettringite into regular $3 \mathrm{CaO} \cdot \mathrm{Al}_{2} \mathrm{O}_{3} \cdot 6 \mathrm{H}_{2} \mathrm{O}$, which results in lower initial strength [17]. However, binding time delay in cement pastes with boric acid depends on $\mathrm{CaO} \cdot \mathrm{B}_{2} \mathrm{O}_{3} \cdot 6 \mathrm{H}_{2} \mathrm{O}$ (or $2 \mathrm{Na}_{2} \mathrm{O} \cdot \mathrm{B}_{2} \mathrm{O}_{3} \cdot 6 \mathrm{H}_{2} \mathrm{O}$ and $2 \mathrm{~K}_{2} \mathrm{O} \cdot \mathrm{B}_{2} \mathrm{O}_{3} \cdot 6 \mathrm{H}_{2} \mathrm{O}$ ) formation, because these compounds precipitate on cement particles and stop its hydration [18]. Also, the effect of cement hydration retardation depends on the amount of alkalis in cement, because lower alkalinity of paste causes dissolution of $\mathrm{CaO} \cdot \mathrm{B}_{2} \mathrm{O}_{3} \cdot 6 \mathrm{H}_{2} \mathrm{O}$. Boric acid and boron frit have deleterious effect on the setting of ordinary cement in the content $0.5-$ $1 \%$ of the concrete weight [19]. However, adding borax in the amount to $1 \%$ has no significant effect on strength of concrete but effects shielding efficiency in thick concrete shields because it reduces the capture gamma rays.

This paper presents findings of research of the effect of borosilicate glass on cement hydration rates and study on pozzolanic activity of fine-ground borosilicate glass. We proposed use of precipitated synthetic silica for increased pozzolanic activity of glass. We studied properties of cement pastes and mortars with a complex admixture of borosilicate glass and synthetic silica.

\section{Experimental}

For the purpose of this research, the following materials were used: ordinary Portland cement: CEM I 32.5 $\mathrm{R}$, borosilicate glass - Pyrex type [20], precipitated synthetic silica with Certificate of Quality Silica [21]. Chemical compositions of these materials are presented in Table 1.
Pozzolanic activity was detected with a chemical method based on reaction of additives with a saturated solution of calcium hydroxide [23]. $2 \mathrm{~g}$ of the tested sample were added to $100 \mathrm{ml}$ of saturated calcium hydroxide solution. Then, the solution was placed in sealed cylinder and shaken properly every 2 days. After 2 days, $50 \mathrm{ml}$ of calcium hydroxide solution was collected from the surface above pozzolana and concentration of calcium hydroxide was determined by titrating with $0.05 \mathrm{M} \mathrm{HCl}$ in the presence of methyl orange indicator. Other $50 \mathrm{ml}$ of saturated calcium hydroxide were poured into the cylinder, shaken again and titrated every 2 days for 30 days. After 30 days, the weight of $\mathrm{CaO}(\mathrm{mg})$ that reacted with $1 \mathrm{~g}$ of additive was determined.

To determine the effect of borosilicate glass on hydration of cement calorimeter type Calmetrix I-Cal $2000 \mathrm{HPC}$ was applied. The rate of heat evolution was followed for the cement pastes with the water to binder ratio of 0.5 . Binder mixtures were made from cement and $5 \%$ additives of glass as cement substitution.

To establish the effect of fine-ground glass on physical properties of cement paste, tests were performed on standard consistency and binding time of paste [24]. The standard consistency of cement paste was determined as a penetration depth of the Vicat plunger to the point of 5-7 $\mathrm{mm}$ from the bottom of the Vicat mould. Vicat needle apparatus was used to determine the initial and final setting time of the cement paste.

Mortar mixtures were designed according to PNEN 196-1 [25]. In order to obtain workability of mortar with additives similar to workability of the control sample, superplasticizer based on polycarboxylate ethers was used. Superplasticizer was used in the amount of $0.5 \%$ of binder weight. Tested mortars were mixed for $3 \mathrm{~min}$ in laboratory mixing machine and then reinforced in two stages for $1 \mathrm{~min}$ on the jolting table. Each mortar was cast in moulds of $4 \times 4 \times 16 \mathrm{~cm}^{3}$. All cuboids of mortars were taken out from moulds after one day, and then cured in water at $293 \pm 1 \mathrm{~K}$. After 2 and 28 days the mortar strength tests were performed. Flexural and compressive strength tests were carried out with hydraulic machine. In order to compare the strength tests results, the strength activity index (SAI, \%) was used, where the strength of mortar with glass additive was compared to the strength of control sample.

Chemical composition of experimental materials

\begin{tabular}{|c|c|c|c|c|c|c|c|c|}
\hline \multirow{2}{*}{ Material } & \multicolumn{7}{|c|}{ Content, wt \% } & \multicolumn{2}{c|}{ Loss on } \\
& $\mathrm{SiO}_{2}$ & $\mathrm{Al}_{2} \mathrm{O}_{3}$ & $\mathrm{Fe}_{2} \mathrm{O}_{3}$ & $\mathrm{~B}_{2} \mathrm{O}_{3}$ & $\mathrm{CaO}$ & $\mathrm{Na}_{2} \mathrm{O}_{\text {eq }}$ & $\mathrm{SO}_{3}$ & ignition, \% \\
\hline Cement & 21.00 & 4.12 & 2.20 & & 63.90 & 0.78 & 3.17 & 2.95 \\
\hline Borosilicate glass & 81.00 & 2.00 & - & 12.0 & 0.50 & 4.50 & & - \\
\hline Synthetic silica & 93.00 & - & 1.00 & - & 1.00 & - & & 5.00 \\
\hline
\end{tabular}

Note: $\mathrm{Na}_{2} \mathrm{O}_{\text {eq }}=$ wt $\% \mathrm{Na}_{2} \mathrm{O}+0.658$ wt $\% \mathrm{~K}_{2} \mathrm{O}$ [22] 
In the work two ways of experiment planning were used: the central composition one and for mixtures. The results are processed using the STATISTICA program.

\section{Results and Discussion}

In its chemical composition, borosilicate glass contains three times less alkali than soda-lime glass, as well as $10 \%$ more of silicon dioxide and about $12 \%$ of boron oxide. Such glass has higher resistance to water; nevertheless, in alkaline environment the surface of the borosilicate glass is degrading. Degree of degradation depends on the coordination state of aluminium and boron ions. In the structure of the examined glass, aluminium ions were four-coordinate, they were strongly bound in glass structure and did not affect the reactivity of the glass. However, $2 / 3$ of boron ions were three-coordinate and $1 / 3$ were four-coordinate [26].

The usage of glass waste as a mineral additive to cement, depends mostly on pozzolanic activity. Therefore, the pozzolanic activity was examined in borosilicate glass in relation to its grain size (Table 2).

As it is seen from Table 2, the reduction in grain size increased pozzolanic activity maximum by 1.6 times. Pozzolanic activity of borosilicate glass with grain size $\leq 0.063 \mathrm{~mm}$ is three times higher compared to soda-lime glass one [27]. Increased pozzolanic activity is related to three-coordinate boron ions, which are more soluble in alkaline environment than four-coordinate ones. The reaction between borosilicate glass and calcium hydroxide varied in time (Fig. 1). Its activity increased three times between 2 and 15 days. At the same time, pozzolanic activity of soda-lime glass increased only twice. After 30 days, the activity grade of borosilicate glass was reduced

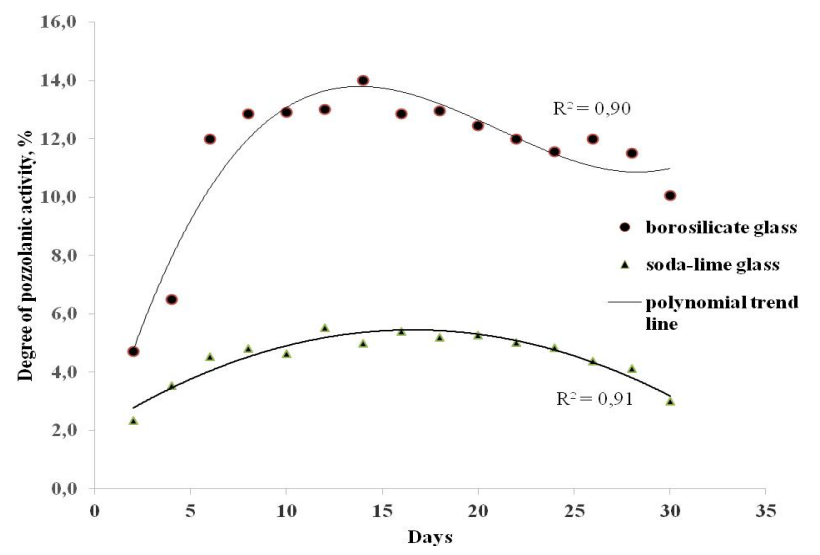

Fig. 1. Degree of pozzolanic activity of the mineral additives to $10 \%$, while soda-lime glass activity was reduced only slightly.

Table 2

Pozzolanic activity of borosilicate glass depending on the grain size

\begin{tabular}{|c|c|}
\hline Grain size, $\mathrm{mm}$ & $\begin{array}{c}\text { Pozzolanic activity, } \mathrm{mg} \mathrm{CaO} / 1 \mathrm{~g} \text { of } \\
\text { additive }\end{array}$ \\
\hline 0.075 & 60.1 \\
\hline 0.063 & 69.6 \\
\hline$\leq 0.063$ & 98.2 \\
\hline
\end{tabular}

To examine the effect of borosilicate glass on cement hydration, calorimetric tests were performed. The results were compared to those obtained when soda-lime glass was used. The calorimetric curves are presented in Figs. 2 and 3.

The introduction of different types of glass instead of cement reduces the heat of cement hydration according to microcalorimetric curve (Fig. 2). One may notice from Table 3 that the lowest hydration heat values were reached for paste with $5 \%$ of borosilicate glass. Comparing to the control sample, the heat decreased by $19 \%$ after $24 \mathrm{~h}$ of hardening and by $16 \%$ after $48 \mathrm{~h}$, and resulted in shorter bonding time. At the same time, soda-lime glass caused reduction in the cement hydration heat by $13 \%$ after $24 \mathrm{~h}$ and by $10 \%$ after $48 \mathrm{~h}$ of hardening.

In the pre-induction stage of cement hydration, the highest heat release rate was noticed in the control sample, while introduction of $5 \%$ of the borosilicate glass decreased hydration rate to $24 \%$. On the other hand, addition of $5 \%$ of the soda-lime glass has reduced the hydration rate only by $8 \%$. After induction, hydration rate was reduced to $16 \%$ for paste with $5 \%$ of soda-lime glass and to $20 \%$ for paste with $5 \%$ of borosilicate glass.

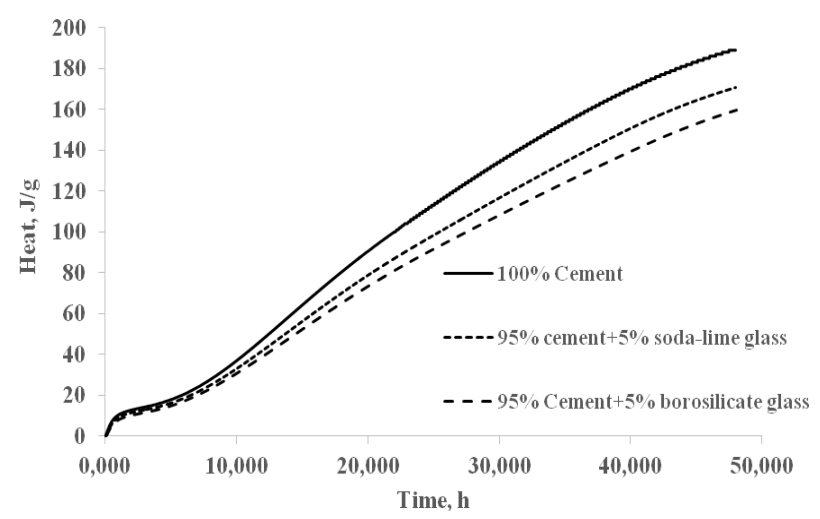

Fig. 2. Heat curves for mixtures of cement with $5 \%$ of sodalime glass and $5 \%$ of borosilicate glass 


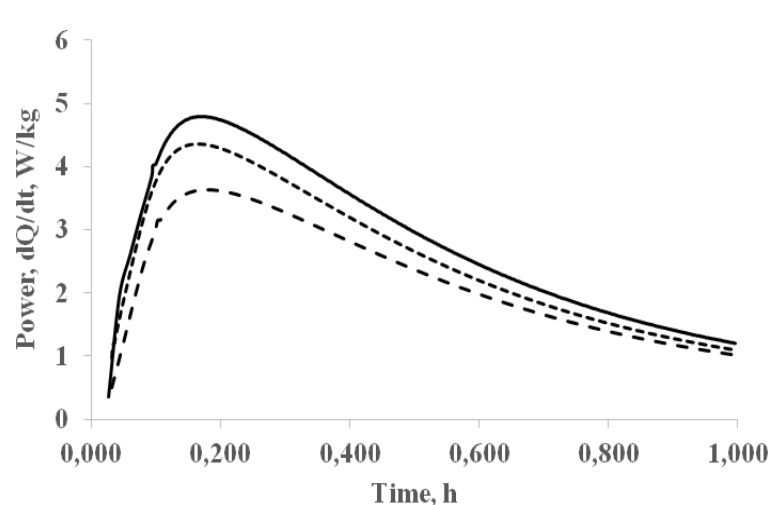

a)

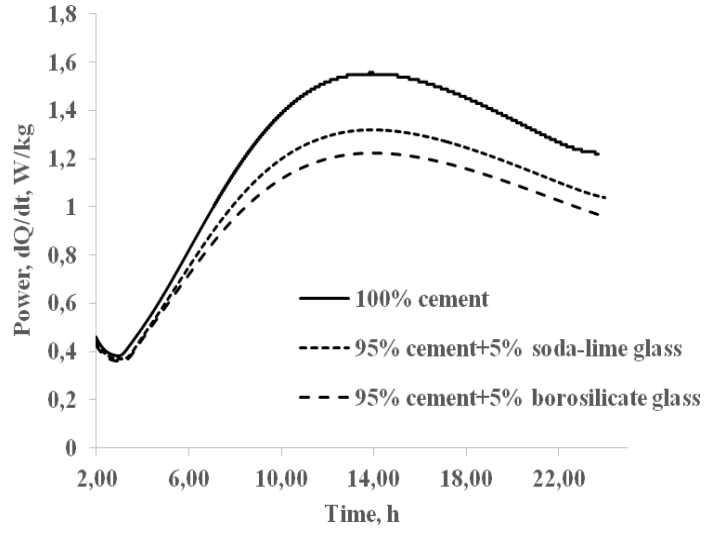

b)

Fig. 3. Power curves on the stage of hydration for mixtures of cement with $5 \%$ of soda-lime glass and $5 \%$ of borosilicate glass in pre-induction stage of hydration (a) and post-induction stage of hydration (b)

Table 3

Characteristic calorimetric values of Portland cement hydration with glass additives

\begin{tabular}{|c|c|c|c|c|}
\hline \multirow{2}{*}{ Mixture, } & \multicolumn{2}{|c|}{$\begin{array}{c}\text { Total heat of cement } \\
\text { hydration, } \mathrm{J} / \mathrm{g}\end{array}$} & \multirow{2}{*}{$\begin{array}{l}\text { Maximum rate of heat } \\
\text { evolution during } \\
\text { hydration of cement in } \\
\text { pre-induction stage, } \\
\text { W/kg }\end{array}$} & \multirow{2}{*}{$\begin{array}{l}\text { Maximum rate of heat } \\
\text { evolution during } \\
\text { hydration of cement in } \\
\text { post-induction stage, } \\
\mathrm{W} / \mathrm{kg}\end{array}$} \\
\hline & after $24 \mathrm{~h}$ & after $48 \mathrm{~h}$ & & \\
\hline $100 \%$ cement & 109.00 & 189.00 & 4.80 & 1.55 \\
\hline $95 \%$ cement $+5 \%$ soda-lime glass & 94.581 & 170.62 & 4.40 & 1.30 \\
\hline $95 \%$ cement $+5 \%$ borosilicate glass & 88.08 & 159.37 & 3.63 & 1.23 \\
\hline
\end{tabular}

We know that boric acid and borax in the amount of $0.1-0.6 \%$ (in relation to cement) are compounds that delay binding [27]. Therefore, the influence of borosilicate glass on the binding time of cement pastes was investigated. Application of fine-ground glass with grain size $\leq 0.063 \mathrm{~mm}$ increased the water consumption of pastes and extended beginning of the binding. However, if binding time for paste with $2 \%$ of borosilicate glass decreased twice, the time for paste with $5 \%$ - only by $15 \mathrm{~min}$ (Table 4 ).

To increase the activity of borosilicate glass the precipitated synthetic silica was used. Composition and pozzolanic activity of complex additives are represented in Table 5 while statistical analysis of the synthetic silica effect is given in Fig. 4.

Pozzolanic activity of borosilicate glass with grain size $\leq 0.063 \mathrm{~mm}$ was 4 times lower than for synthetic silica. By replacing $1 \%$ of the glass with silica, pozzolanic activity increased to $9.4 \mathrm{mgCaO} / \mathrm{g}$ of additive, according to regression function (Fig. 4).

Strength tests were performed on mortars with $2 \%$ and $5 \%$ of borosilicate glass after 2 and 28 days, (Table 6 ). In comparison with the control sample, addition of glass resulted in the decrease of initial strength. Only after 28 days, the strength of mortar with $2 \%$ of glass was slightly higher. Addition of greater amount of glass resulted in decrease of standard compressive strength by around $20 \%$.

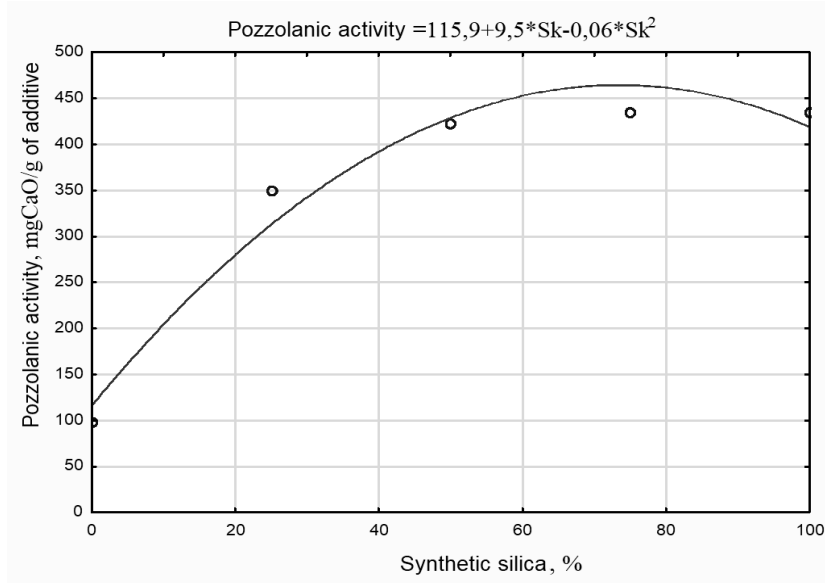

Fig. 4. Model of the regression function - relation of the glass pozzolanic activity and the content of synthetic silica 
Binding times for the tested pastes

\begin{tabular}{|c|c|c|c|}
\hline Glass content, $\%$ & Standard texture, $\%$ & Beginning of the binding, min & Binding time, min \\
\hline 0 & 27 & 270 & 50 \\
\hline 2 & 28.5 & 285 & 25 \\
\hline 5 & 29 & 285 & 35 \\
\hline
\end{tabular}

Pozzolanic activity of additives and their mixtures

\begin{tabular}{|c|c|c|}
\hline \multicolumn{2}{|c|}{ Amount of additive in the mixture, $\%$} & \multirow{2}{*}{ Pozzolanic activity, mg CaO/g of additive } \\
\hline Borosilicate glass & Synthetic silica & 98.2 \\
\hline 100 & 0 & 350.23 \\
\hline 75 & 25 & 422.68 \\
\hline 50 & 50 & 434.86 \\
\hline 25 & 75 & 434.76 \\
\hline 0 & 100 & \\
\hline
\end{tabular}

Table 6

Results of strength tests for mortars

\begin{tabular}{|c|c|c|c|c|}
\hline \multirow{2}{*}{ Glass content, \% } & \multicolumn{2}{|c|}{ Flexural strength, MPa } & \multicolumn{2}{|c|}{ Compressive strength, MPa } \\
\cline { 2 - 5 } & 2 days & 28 days & 2 days & 28 days \\
\hline 0 & 5.2 & 8.6 & 17.3 & 44.4 \\
\hline 2 & 3.8 & 8.9 & 16.69 & 45.3 \\
\hline 5 & 3.9 & 8.0 & 15.61 & 35.95 \\
\hline
\end{tabular}

Table 7

Composition of the complex additive in cement mortars

\begin{tabular}{|c|c|c|c|}
\hline \multicolumn{2}{|c|}{ Code values } & \multicolumn{2}{c|}{ Real values, \% } \\
\hline Synthetic silica (S) & Borosilicate glass (B) & Synthetic silica (S) & Borosilicate glass (B) \\
\hline+1 & +1 & 1.5 & 4.5 \\
\hline+1 & -1 & 1.5 & 4.5 \\
\hline-1 & +1 & 0.5 & 1.5 \\
\hline-1 & -1 & 0.5 & 1.5 \\
\hline 0 & -1 & 1 & 4.5 \\
\hline 0 & +1 & 1 & 2.5 \\
\hline+1 & 0 & 1.5 & 2.5 \\
\hline-1 & 0 & 0.5 & 2.5 \\
\hline
\end{tabular}

Table 8

Strength tests results for mortars from the complex additive after $\mathbf{2}$ and $\mathbf{2 8}$ days

\begin{tabular}{|c|c|c|c|}
\hline \multicolumn{2}{|c|}{ Flexural strength, MPa } & \multicolumn{2}{c|}{ Compressive strength, MPa } \\
\hline 2 days & 28 days & 2 days & 40.9 \\
\hline 4.51 & 9.5 & 16.2 & 35.2 \\
\hline 5.04 & 7.17 & 16.3 & 45.3 \\
\hline 5.37 & 8.74 & 19.0 & 43.1 \\
\hline 4.83 & 8.77 & 17.0 & 39.1 \\
\hline 4.19 & 8.45 & 13.3 & 41.8 \\
\hline 4.72 & 8.29 & 17.0 & 40.1 \\
\hline 4.99 & 8.49 & 17.9 & 45.1 \\
\hline 4.19 & 8.73 & 18.7 & 43.4 \\
\hline
\end{tabular}




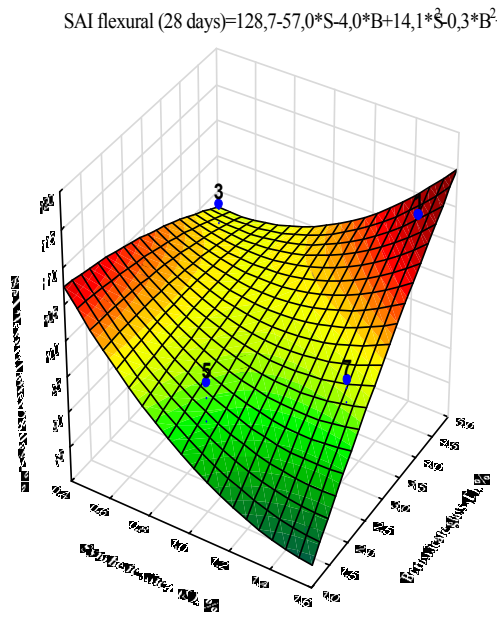

a)

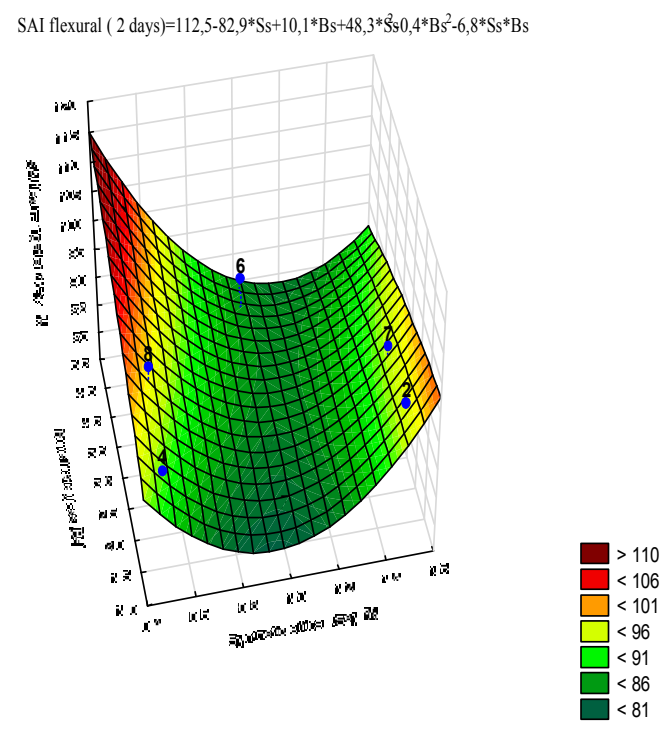

Fig. 5. SAI-flexural of cement mortars after 2 (a) and 28 (b) days of hardening

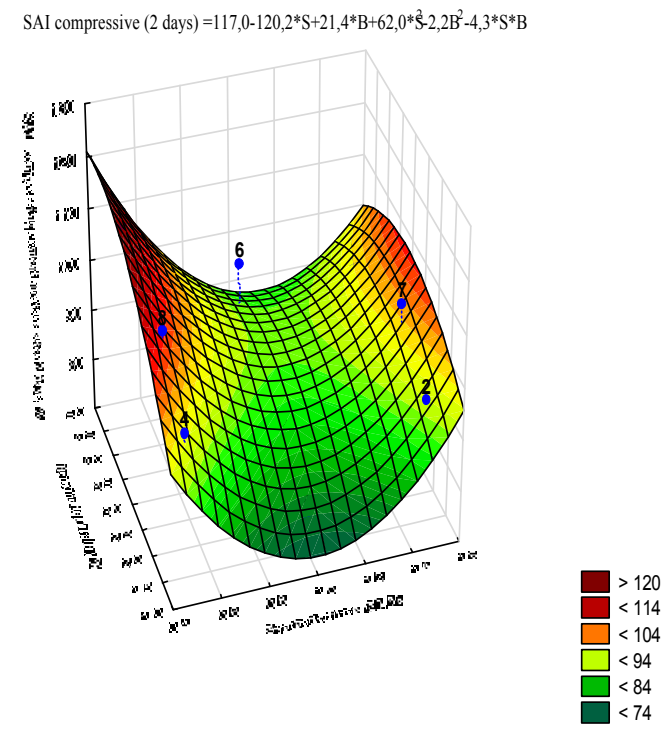

a)

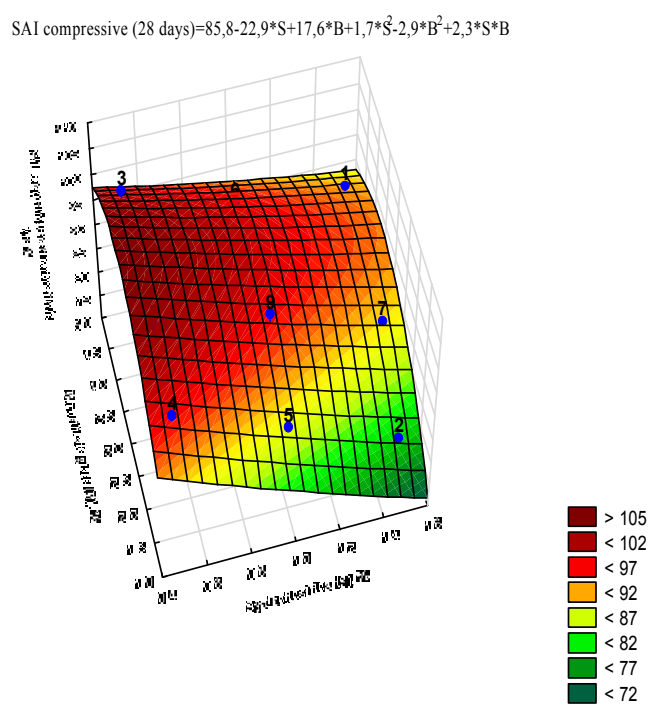

b)

Fig. 6. SAI-compressive of cement mortars after 2 (a) and 28 (b) days of hardening

In order to establish effect of complex additives (borosilicate glass and synthetic silica) on the strength, two-components experiment was used. Content of borosilicate glass varied from 1.5 to $4.5 \%$ relative to cement weight, while synthetic silica content - from 0.5 to $1.5 \%$. Composition of complex additive and strength tests results are presented in Tables 7 and 8 , and statistics for SAI-flexural and SAI-compressive - in Figs. 5 and 6, respectively.
Based on statistics, synthetic silica had significant impact on the strength of mortars in complex additive. With complex additives content $(0.5 \%$ of synthetic silica, and $2-5 \%$ of borosilicate glass) the initial compressive strength increased by $10 \%$, while standard compressive strength increased only slightly. The flexural strength, at the same time, increased insignificantly for the given mixture of complex additives. However, increase in the synthetic silica content above $05 \%$ resulted in decreased 
flexural and compressive strength after 2 and 28 days of hardening of cement mortars.

\section{Conclusions}

Pozzolanic activity of the borosilicate glass (with particle size $\leq 0.063 \mathrm{~mm}$ ) was found to be equal to $98.2 \mathrm{mg} \mathrm{CaO} / \mathrm{g}$ additive. When compared to pozzolanic activity of soda-lime glass, it is three times higher.

To increase activity of borosilicate glass the precipitated synthetic silica was used. Replacement of $1 \%$ of borosilicate glass increased the pozzolanic activity to $9.4 \mathrm{mg} \mathrm{CaO} / \mathrm{g}$ of additive.

Calorimetric tests have shown that incorporation of borosilicate glass in the amount of $5 \%$ decreased heat hydration of cement paste. In the pre-induction stage of cement hydration, introduction of the borosilicate glass decreased hydration rate to $24 \%$, while addition of the soda-lime glass reduced the hydration rate only by $8 \%$. The hydration rate after induction was reduced to about $20 \%$ for pastes with both soda-lime and borosilicate glass.

By adding $2 \%$ of fine-ground borosilicate glass, binding time for paste was two times shorter and compressive strength slightly increased. However, the increase in borosilicate glass content to $5 \%$ resulted in the decrease in compressive strength by $10 \%$ and $20 \%$ (in comparison with the control mortar) after 2 and 28 days of hardening, respectively.

Complex additive of borosilicate glass $(2-5 \%)$ and synthetic silica $(0.5 \%)$ increased initial standard compressive strength of cement mortar by $10 \%$ and slightly increased standard compressive strength.

\section{References}

[1] Najduchowska M., Rożycka K., Rolka G.: Prace ICiMB, 2014, 17, 46.

[2] Sadiqul Islam G., Rahman M.: Int. J. Sustain. Built Environ., 2017, 6, 37. https://doi.org/10.1016/j.ijsbe.2016.10.005

[3] Shevchenko W., Kotsay G.: Chem. Chem. Technol., 2015, 9, 231. https://doi.org/10.23939/chcht09.02.231.

[4] Gorospe K., Booya E., Ghaednia H., Das S.: Constr. Build. Mater., 2019, 210, 301.

https://doi.org/10.1016/j.conbuildmat.2019.03.192

[5] Lee J.-C., Jang B.-K., Shon C.-S. et al.: J. Clean. Prod., 2019, 210 , 638.

https://doi.org/10.1016/j.jclepro.2018.11.033

[6] Gómez-Soberón J., Cabrera-Covarrubias F., Almaral-Sánchez J., Gómez-Soberón M.: Adv. Mater. Sci. Eng., 2018, 4, 1.

https://doi.org/10.1155/2018/1386946

[7] Guo M.-Z., Tu Z., Poon C.: Constr. Build. Mater., 2018, 179, 138. https://doi.org/10.1016/j.conbuildmat.2018.05.188

[8] Elaqra H., Al-Afghany M., Abo-Hasseira A.: Constr. Build.

Mater., 2018, 179, 326

https://doi.org/10.1016/j.conbuildmat.2018.05.263

[9] Lee G., Poon C., Wong Y., Ling T.: Constr. Build. Mater., 2013, 38, 638. https://doi.org/10.1016/j.conbuildmat.2012.09.017
[10] Mrowiec K., Kubica S., Kuczyńska H.: Chemik, 2011, 11, 1212. [11] Shao Y., Lefort T., Mora S., Rodriguez D.: Cement Concrete Res., 2000, 30, 91. https://doi.org/10.1016/S0008-8846(99)00213-6

[12] Shevchenko V., Kotsai G.: Glass Phys. Chem., 2017, 43, 595. https://doi.org/10.1134/S1087659617060141

[13] Shevchenko V., Kotsai G.: Glass Phys. Chem., 2016, 42, https://doi.org/10.1134/S1087659616030123

[14] Scholze H.: Glass: Nature, Structure, and Properties. SpringerVerlag 1990.

[15] Yaschyshyn J.: Technologia skla. Fizyka i Khimia Skla.

Politechnika Lvivska, Lviv 2008.

[16] Łukowski P.: Modyfikacja Materialowa Betonu. Polski cement, Krakow 2016.

[17] Kurdowski W.: Chemia cement i betonu. Wydawnictwo Polski cement, Warszawa 2010.

[18] Davraz M.: Acta Phys. Pol. A, 2015, 128, 26.

https:/doi.org/10.12693/APhysPolA.128.B-26

[19] Kharita M., Yousef S., Alnassar M.: Progr. Nucl. Energ., 2011, 53, 207. https://doi.org/10.1016/j.pnucene.2010.09.012

[20] www.continentaltrade.com.pl/szklo-borokrzemowe

[21] Certificate of quality silica WL-160 (Powder). N 20111128. http://en.well-t.com.cn

[22] EN 196-2:2013: Cement test methods--Part 2: Chemical Analysis of cement. https://standards.globalspec.com/std/1611318/EN 20196-2

[22] Butt J., Sychev M., Timashev V.: Prakticum po Khimicheskoi Technologii Sviazuyushchikh. Vyshaya schkola, Moskva 1973.

[23] EN 196-3:2009. Cement test methods-Part 3: Determination of constraint times and volume constant.

https://standards.globalspec.com/std/10061462/EN 20196-3.

[24] PN-EN 196-1: 2016. Cement Test Methods-Part 1:

Determination of strength.

https://standards.globalspec.com/std/10010985/EN 20196-1

[25] Kotsay G.: Quest. Chem. Chem. Technol., 2011, 5, 142.

[26] Kotsay G., Kuźniecki M., Pilarczyk S.: Teoria i Praktyka Budownictwa, 2013, 755, 189.

[27] Kurdowski W.: Chemia Cementu i Betonu. Wydaw. PWN, Warszawa 2010

Received: April 10, 2019 / Revised: May 07, 2019 / Accepted: October 29, 2019

\section{ВПЛИВ ВІДХОДІВ БОРОСИЛІКАТНОГО СКЛА I СИНТЕТИЧНОГО КРЕМНЕЗЕМУ НА ВЛАСТИВОСТІ ЦЕМЕНТНИХ ПРОДУКТІВ}

Анотація. Представлено результати дослідження впливу відходів боросилікатного скла на властивості цементного розчину. Встановлено, що боросилікатне скло містить в три рази менше лугів ніж содово-вапнякове скло і близько $12 \%$ оксиду бору, тому дане скло має в три рази вищу пуцоланову активність. Синтетичний кремнезем застосовано для підвищення активності скла. Показано, щчо заміна 1\% боросилікатного скла синтетичним кремнеземом підвищуе пуцоланову активність до 9,4 мг СаО/2 добавки. Встановлено, що додавання 5\% боросилікатного скла замість иементу, зменшує стандартну міцність на стиск на 20\%. Однак, використання комплексної добавки боросилікатного скла (2-5\%) i синтетичного кремнезему (0,5\%) дає можливість збільшити початкову міиність на стиск иеементних розчинів до $10 \%$.

Ключові слова: боросилікатне скло, синтетичний кремнезем, пуцоланова активність, міцність. 